\title{
South Asia and the Creation of the International Refugee Regime
}

\author{
Pia Oberoi
}

\section{Abstract}

This paper traces the initial interaction of the states of South Asia with the formalized international refugee regime, as embodied within the Office of the UNHCR. It explores the debates surrounding the creation of the Office and the 1951 Refugee Convention, and attempts to analyze the disillusionment felt by India and Pakistan with the outcome of these deliberations. Both these states arrived at the United Nations in this period with the burden of hosting up to 14 million Partition refugees weighing heavily on their inexperienced shoulders. Expecting that any international regime created for the relief of refugees would take into account this vast refugee crisis, India and Pakistan were disappointed to realize that cold war politics largely dictated the eventual outcome of the content of the Convention and the mandate of the UNHCR. Fifty years later, neither state has acceded to the 1951 Refugee Convention, preferring to interact with UNHCR on a strictly ad hoc basis. This paper argues that many reasons for the hesitancy with which these states approach UNHCR can be traced to their initial understanding of the mandate of the Office.

\section{Résumé}

Cet article retrace l'interaction initiale des états de l'Asie du sud avec un régime international de droits des réfugiés formalisé, comme incorporé dans le Haut Commissariat. Il explore les débats qui ont entouré la création de cette institution ainsi que la Convention de 1951 relative au statut des réfugiés, et tente d'analyser les désenchantements de l'Inde et du Pakistan avec les résultats de ces délibérations. Ces deux états sont arrivés aux Nations Unies pendant cette période là, portant sur leurs épaules sans expérience le lourd fardeau de l'hébergement de près de 14 millions de réfugiés de la Partition. S'attendant à ce qu'un régime international crée tout spécialement pour s'occuper du bien-être des réfugiés prendrait tout naturellement en compte cette immense crise de réfugiés, l'Inde et le Pakistan furent déçus de réaliser que ce furent les impératifs politiques de la guerre froide qui déterminèrent les résultats finals pour ce qui est du contenu de la Convention et aussi bien que du mandat du HCR. Cinquante ans plus tard, ces deux états n'ont toujours pas accédé à la Convention de 1951 relative au statut des réfugiés, préférant interagir avec le HCR au cas par cas. L'article soutient que beaucoup des raisons expliquant les hésitations de ces deux états envers le HCR peuvent être retracées à leur compréhension initiale du mandat du Haut Commissariat.

గ 1 he states of South Asia ${ }^{1}$ have long had an ambivalent relationship with the United Nations High Commissioner for Refugees (UNHCR). At times, this has resulted in a remarkable partnership, as was the case in 1971 when India and UNHCR jointly provided relief to one of the largest and most traumatic refugee movements in contemporary history. At other times, however, the relationship has been fractious and hostile. This was the case when UNHCR threatened to withdraw from Bangladesh in 1992 over the issue of forced repatriation, or when it did in fact close its branch office in New Delhi for a period from June 1975, much to the displeasure of the Indian government. The South Asian region has witnessed some of the largest flows of forced migrants in recent history, and continues to host over 10 per cent of the world's refugees. Currently, UNHCR plays a not inconsiderable role in the management of situations of forced displacement in South Asia. It has assumed responsibility for "urban refugees" in India, the largest caseload of such refugees recognized by the Office. In addition, it is providing varying levels of relief to the Afghan refugees in Pakistan, Rohingya Muslim refugees in Bangladesh, and Tamil IDPs in Sri Lanka.

This article seeks to explore the origins of the relationship between UNHCR and the states of South Asia. None of 
these states has acceded to the 1951 Convention relating to the Status of Refugees, despite several attempts by UNHCR over the years to promote accession. Yet, as will be seen below, India and Pakistan were initially enthusiastic about the creation of a formalized international refugee regime as embodied in the Office of the UNHCR. ${ }^{2}$ Both countries were in the midst of a vast refugee crisis while the issue was being debated within the United Nations. By 1951, an estimated 14 million people had traversed the newly created international border between the two states in search of refuge from persecution, as religious particularism engulfed the subcontinent. In such a situation, India and Pakistan expected that this debate would address issues of immediate relevance to them. Yet by the time the debate reached its final stages, both states had, in effect, withdrawn from the deliberations. This article will trace the process whereby India and Pakistan came to the conclusion that the formalized international refugee regime was largely inimical to their interests. Given that sources for this facet of Indian and Pakistani history are relatively limited, much of the material included here is taken from the travaux preparatoires of the United Nations debates. In order to analyze the policy attitude of South Asian states towards this issue, however, it is first necessary to locate these states within an emergent United Nations.

\section{India}

On August 15, 1947, India became an independent member of the international community, although its interaction with international organizations preceded this date. It had been a participant in the Versailles Conference of 1919, and had been represented in the League of Nations. Under the first prime minister, Jawaharlal Nehru, India looked to set itself up as a major player on the international stage. In the early years of independence, India's policy of non-alignment was well served within the United Nations, of which it was a founding member. Despite its relative poverty and consequent lack of international stature as determined by material and positional power, the General Assembly gave it a forum in which to articulate a robust, if idealistic, defence of Third World solidarity and detachment from coldwar power politics. It is, therefore, not surprising to find that India was initially well represented in the debate on the creation of a new international refugee regime. As the first state to shed its colonial status in the aftermath of the Second World War, India was in a position of leadership among a group of countries that would eventually be known as the Third World coalition. It was the first to raise the question of racial discrimination in South Africa at the
United Nations and under Nehru was an early advocate of nuclear non-proliferation. As the world debated issues of human rights, as they pertained to the question of forced migrants as well as other categories of persons, India was drawing up its first constitution. This document was inspired to a great extent by the United Nations Charter, and thus included provisions on respect for the human rights of persons within the territory of India, and the promotion of fundamental freedoms. ${ }^{3}$ On September 25, 1948, Mrs. Vijayalakshmi Pandit, India's permanent representative to the United Nations, who was the first woman to be elected president of the General Assembly in 1953, stated, "India has shown, in the shaping of its Constitution [that the words of the UN Charter] were no empty phrases, but a living inspiration." 4

\section{Pakistan}

Following the partition of British India, Pakistan emerged on August 14, 1947, as the new homeland for the Muslims of the Indian subcontinent. Shortly after Pakistan was admitted to the United Nations, on September 30, 1947, the first prime minister of Pakistan, Mohammed Ali Jinnah, declared, "Pakistan will never be found wanting in extending its moral and material support to the oppressed ... and [in] upholding the principles of the United Nations Charter." As was the case with its giant neighbour, in the early years of its independent existence Pakistan was enthusiastic about the potential of the United Nations. As a relatively weak state, it looked to harness the moral power of that organization to renegotiate traditional power politics. Along with championing the cause of anti-colonialism, Pakistan played a leading role in the debate on the Palestine issue and on the treatment of South African citizens of Indian origin. During this period, the vexing issue of relations with India, especially over the disputed territory of Kashmir, brought Pakistan to the debating chambers and dispute-settlement mechanisms of the United Nations more than once. In the immediate period following India's referral of the Kashmir question to the Security Council on January 1, 1948, Pakistan argued vociferously for a plebiscite in the territory. A subsequent Security Council resolution calling for a ceasefire and plebiscite was accordingly considered a "vindication of [the Pakistan] stand by the United Nations." ${ }^{\text {A }}$ As will be seen, and consequent to its early positive view of the United Nations, Pakistan also played an active role in the discussions and committees set up to debate the international refugee regime.

So, in the aftermath of the Second World War, India and Pakistan were among the first Afro-Asian colonial territories 
to win their independence. This enabled them to seize a privileged position of leadership in the new and relatively egalitarian General Assembly. As one author states, "many of the issues which came up for consideration at the time related to the right of self-determination and independence of peoples who were still struggling to be free, and India and Pakistan, having been the most prominent sufferers from imperialism, were regarded as the natural spokesmen." 7 Gradually, however, considerations of national interest tempered the unqualified enthusiasm with which these states approached the United Nations within this period. In the case of the Kashmir dispute in particular, India and Pakistan came to have widely divergent views on the proper role of the United Nations within that conflict. However, on the question of refugee relief and rehabilitation, both countries displayed a remarkable convergence of views. In a debate within the General Assembly's Ad Hoc Political Committee in December 1950, accordingly, the Pakistani representative declared,

after a series of conferences in connection with refugees, millions of Hindus had returned to Pakistan and millions of Muslims had gone back to India, despite the fact that the two countries had been waging an undeclared war for several months. The Governments of Pakistan and India had never thought it proper to link the question of settlement of the refugee problem or their repatriation with any other issue outstanding between them. ${ }^{8}$

\section{Partition Refugees}

India and Pakistan came to these preliminary debates as the Partition refugee crisis was reaching a breaking point. By end of 1947, over 9 million refugees had crossed the IndiaWest Pakistan border, in both directions, occasioning the need for colossal relief and rehabilitation efforts. ${ }^{9}$ Apart from relatively minor contributions from foreign charitable organizations, the two newly independent states shouldered the entire responsibility for the refugees, which ranged from provision of emergency transit camps, transport, and supplies, to the construction of permanent housing colonies. An early indication of the extent of the international community's interest in the refugee problem of the subcontinent is provided by V. K. Krishna Menon, defence minister under Nehru, who visited several countries of Europe in 1946 as a personal representative of the Indian Ministry for External Affairs. By August 1946, following a call for "direct action" by the Muslim League, riots had broken out in several districts of British India, leading to a near collapse of the civil administration, and the mass displacement of several thousands. It was in the context of this situation of near anarchy and the beginnings of an unprecedented movement of peoples, that Menon stated, "the outstanding and overall impression left on my mind ... are ... the very limited reference to our internal problems and difficulties." 10 The Indian subcontinent was thus given early indication of the marginal impact its refugee crisis was to have on the world community. However, both states would continue to take active part in the United Nations debate on the international refugee regime, in keeping with their early enthusiasm for the goals of that organization. ${ }^{11}$

\section{Refugees and the Post-War International Community}

The issue of refugee protection was, by the end of the Second World War, of some concern to the international community. This concern was mainly focused on European refugees, the majority of whom had been created by war hostilities, but increasingly included persons fleeing Communist bloc states. In the immediate aftermath of the war, the lead refugee agency was the International Refugee Organization (IRO). This organization had come into existence in place of the Intergovernmental Committee for Refugees and the United Nations Relief and Rehabilitation Administration (UNRRA) in July 1947. Mandated to operate for a limited period of time, the IRo nevertheless "treated the refugee problem in totality." ${ }^{12}$ In other words, it was responsible for issues of legal protection and relief, and of resettlement of refugees not just in Europe, but those who had fled to countries such as India and to the Middle East. By the late 1940s, however, it became apparent that the question of refugees, even just that of European refugees, was no closer to a permanent solution. On July 7, 1947, the IRO General Council adopted Resolution 39, which provided for termination of the organization's activities. Consequently, it gradually reduced its operations, and was finally wound up in early $1952 .{ }^{13}$

So, by 1947 , the question of refugees and stateless persons was being debated within the United Nations. During these discussions, the issue was divided into the following: provisions for the functioning of a High Commissioner's Office for Refugees; definition of the term refugee; problems of assistance to refugees and institution of a draft Convention relating to the Status of Refugees. At the fourth session of the General Assembly, on December 3, 1949, a decision was made to accept in principle the establishment of a United Nations High Commissioner for Refugees on January 1, 1951, the date that the IRO was expected to dissolve. This was followed by a request to the Economic and Social Council (ECOSOC) to establish the details of a statute 
for the new agency. In 1951 the General Assembly decided to convene a Conference of Plenipotentiaries in Geneva, which was intended to complete the drafting and signing the Refugee Convention.

\section{The Role of India and Pakistan}

As has been noted, India and Pakistan were active players in the initial discussions on blueprints for a new international refugee regime. In November 1947, at the seventyninth meeting of the Third Committee, India submitted a draft resolution "with a view to conciliating the various points of view expressed in the previous Resolutions," in which it stated its position that "the main task concerning displaced persons is to encourage and assist in every possible way their early return to their countries of origin." ${ }^{14}$ At a subsequent meeting, the committee set up a drafting subcommittee of thirteen members, which included a representative of India, and which took as the basis for discussions a new draft resolution prepared by India. Both India and Pakistan at the outset declared their sympathy with the aims of this new refugee regime. Consequently, on $\mathrm{Au}-$ gust 6, 1949, the Indian representative at the Economic and Social Council declared that India was "fully prepared to co-operate in the drafting of Conventions for the legal protection of refugees, provided they were consistent with its own national citizenship laws, which were at the moment in the process of being framed.". ${ }^{15}$

\section{United Nations Debate: The Refugee Definition}

As the discussion on the future form and scope of a new refugee organization gathered momentum in the United Nations, one major point of debate was the definition of a refugee to be applied within the new regime. The discussion was essentially divided between states that favoured a broader definition than that contained within the Iro constitution (spearheaded by the United Kingdom, and supported by India and Pakistan), and others who were opposed to extending the IRO definition (led by the United States delegation). ${ }^{16}$ Broadly speaking, the majority of representatives of the emerging "Third World" contested the application of temporal and spatial limitations. These states made it clear that they considered it the duty of the United Nations, if the claims that it was a truly egalitarian organization were to be justified, to substantially extend its understanding of "a refugee."

Yet, the United States, wary of asking the United Nations to "sign a blank cheque," argued for a refugee definition that was consonant with the IRO constitution. This would mean in effect that the jurisdiction of the High Com- missioner's Office would extend only as far as persons in Europe who had become refugees as a result of the Second World War. These refugees, according to some delegations, were the reason that the issue of forced migrants had been placed on the agenda of the General Assembly in the first place. To extend the scope of these discussions beyond such defined limits would leave the United Nations liable to "assume responsibilities too readily. ${ }^{{ }^{17}}$ As Eleanor Roosevelt stated, "The Pakistan representative had in fact suggested that the General Assembly accept responsibility for all categories of refugees existing in any part of the world, and also for such other categories as might develop in the future." ${ }^{18}$ Opposition to this view was led by the delegation of the United Kingdom, which argued, in common with the states of the subcontinent, that a regime centred on the United Nations should provide minimum guarantees for all refugees, irrespective of their origins. ${ }^{19}$

While the debate sought to define the status of persons who might need protection in the future, India and Pakistan attempted to call attention to the millions of refugees on their territory at that time. As mentioned previously, the two new states were struggling with the burden of caring for a vast refugee population. This was complicated by the exigencies of nation building faced by the relatively impoverished states. Both delegations accordingly attempted repeatedly to assert that the Partition refugees deserved protection within the new international refugee regime. The Pakistani representative thus claimed that

after the end of [the Second World War] ... other events had taken place in other parts of the world. If the United Nations was to be entrusted with the problem [of refugees], it should consider it on a worldwide basis. For example, a year and a half earlier, Pakistan had been compelled to receive from 6 to 7 million refugees coming from various part of India. ${ }^{20}$

In addition, the Indian delegate argued,

it had to cope with its own refugee problem-indeed there were 6 million Indian refugees who had to be looked after and resettled. He hoped the United Nations would acknowledge that India was performing an international as well as a national duty by helping those people $\ldots{ }^{21}$

Other delegations claimed, however, that the situation facing the Indian subcontinent was that of internal refugee flight, since in both cases the refugee groups did not lack the protection of a government. Consequently, in their opinion, since there was no need for the legal protection of these refugees, this was not a matter with which these deliberations were concerned. ${ }^{22}$ Yet in addition to India and Pakistan, other delegations argued for the inclusion within 
the new regime of groups of refugees that would be excluded if the proposed limitations of time and space were applied. Thus, several Middle Eastern countries argued for the inclusion in the regime of the Palestinian refugees, ${ }^{23}$ and the Greek delegate urged consideration of the approximately 700,000 Greeks who had been forced to seek refuge as a result of the civil war.

\section{United Nations Debate: Legal protection vs. Material Assistance}

Another major debate within these discussions, and related to the plea of the Indian and Pakistani delegates to include consideration of those displaced at Partition, was on the proposed need to distinguish between international legal protection and material assistance for refugees. ${ }^{24}$ Contending that the greatest need of refugees bereft of the protection of a state was the legal assistance of the international community, some states challenged the notion that the proposed Office of the High Commissioner should be responsible for the provision of material aid to refugees. While India and Pakistan agreed that the legal protection of refugees was in many ways the cornerstone of the international refugee regime, they argued from their perspective that the guarantee of legal rights without concomitant material assistance was a hollow concept. The Indian representative, Mrs. Kripalani, consequently asserted that "it was true that [the Partition] refugees were not stateless; the State ensured their protection. But statelessness was often a lesser hardship than lack of food, clothing, shelter and work." ${ }^{25}$ The Pakistani representative added in agreement that "although statelessness was a great privation, it was after all the least of the misfortunes to deal with which the IRo had been set up." 26

However, the strategic marginality of the Indian subcontinent and the scale of the problem with which it was confronted, made it difficult to gain a sympathetic ear among powerful states. In a private conversation, Phillip Burnett, a member of the American uN delegation, explained to Mr. Bokhari, spokesperson of the Pakistani delegation, that the extension of material aid to the Partition refugees under the mandate of the High Commissioner's Office "would not be regarded favourably by the U.S. since the problem was so enormous." ${ }^{27}$ Yet India and Pakistan, making their debut on the world stage as independent states, looked to the United Nations to represent the postwar international community in its entirety. The recently adopted Universal Declaration for Human Rights appeared to them to make this a pressing duty. In addition, the massive burden of the Partition refugees made them loath to accept a partial regime, in which their own concerns were sidelined, if not neglected. ${ }^{28}$

The financial implications of providing emergency relief to millions of Partition refugees meant that, by 1947, India and Pakistan were no longer able to continue material contributions to the IRO. As discussion in the United Nations centred on the future of the IRO, the issue of expenses was one that both states, along with other nonEuropean developing countries, viewed with some justified alarm. Indian and Pakistani representatives argued against having to shoulder the burden of IRo refugees, considering instead that this organization was well able to complete its task before being dissolved. Several commentators have noted that one of the pressing reasons for the reformulation of the post-war international refugee regime was the need to create secure conditions in order that Europe might share the burden of its refugees with other parts of the world. ${ }^{29}$ Some European states, such as France, believed that it was time for all members of the United Nations to contribute to the resettlement of the remaining war refugees, as well as the growing influx of refugees from the Eastern bloc. Yet, in the context of their own refugee and economic problems, India and Pakistan considered unfair the notion that they should be expected to support European refugees, ${ }^{30}$ especially when they were not expected to gain any reciprocal benefit for the refugees on their own territory.

By November 17, 1949, the joint draft resolution on the establishment of the Office of the United Nations High Commissioner for Refugees was ready to be put to a vote in the Third Committee. Following strong statements in opposition to the proposed Office, ${ }^{31}$ India and Pakistan voted against the resolution. On December 3, 1949, India abstained from and Pakistan voted against General Assembly Resolution 319 (IV), which established the Office of UNHCR, and which was eventually passed by thirty-five votes to seven, with thirteen abstentions. ${ }^{32}$

\section{Debate on the Refugee Definition Continues}

By 1950, debate in the United Nations was centred on defining the scope and nature of a Convention relating to the Status of Refugees as well as a statute for the High Commissioner's Office. Pakistan continued to oppose the limitations being placed on the refugee definition. In the eleventh session of ECOSOC, the Pakistani delegate stated that "his Government could not accept the definition of the term 'refugee' as given in the draft Convention. That definition covered European refugees only, and completely ignored refugees from other parts of the world." ${ }_{33}$ In the Third Committee of the General Assembly, Belgium, Canada, Turkey, 
and the United Kingdom presented a joint amendment to the draft statute, which attempted to broaden the definition of persons falling under the competence of the High Commissioner's Office. In removing the limitations in time and space, this amendment and others submitted by such states as Egypt, Lebanon, and Saudi Arabia recognized, in the words of the Chilean delegate, that "it was the duty of the United Nations to extend international protection to every person who, for reasons beyond his control, could no longer live in the country of his birth." ${ }^{34}$

However, this was opposed by the United States and France, which continued to favour a more limited "definition by categories" that would specify the particular groups to be covered. They argued that the limited definition they were promoting included all refugee groups "who were in need of international protection," and also that it was inappropriate at this stage to make decisions concerning future groups of refugees. ${ }^{35}$ By this stage, India appears to have decided that the proposed regime was in many ways a creature of the Western world, and was therefore attempting to ensure a minimal obligatory engagement with the regime. In August 1950, accordingly, the Indian delegate noted, "the Indian delegation had opposed the broad definition of the term 'refugee' . . because the broad definition would make a satisfactory solution of certain problems connected with refugees less probable inasmuch as it would not be possible to determine in advance exactly what categories of refugees would be covered by it." ${ }_{36}$ Shortly thereafter, in a comment on the report of the Ad Hoc Committee on Statelessness and Related Problems, India, in the light of its "most difficult problem of rehabilitating a very large number of refugees from Pakistan," declared its inability to host any European refugees. It asserted that the treatment of any "European refugees" would therefore continue to be governed by the same laws as were applicable to foreigners in general.

\section{India and Pakistan Disillusioned}

Following their disappointment at the debate in the Third Committee the previous year, both India and Pakistan had largely abstained from the above discussions. However, the Indian delegate spoke briefly at the Third Committee debate in December 1950, in order to clarify the position of her country, and it is worth quoting at some length from that statement in order to get a sense of the attitude of India (which was largely shared by Pakistan) towards the ongoing debate. She stated,

the United Nations should try to help not only special sections of the world's population, but all afflicted people every- where. Suffering knew no racial or political boundaries; it was the same for all. As international tension increased, vast masses of humanity might be uprooted and displaced. For the United Nations to attempt a partial remedy involving discrimination, whether accidental or deliberate, would be contrary to the great principles of the Charter... The Indian delegation had [previously] been in favour of a limited definition [of the term refugee] because it was fully and painfully conscious of the limitations of the whole project that was being considered. Rather than become a party to such an unreal attempt, the Indian delegation had preferred to abstain from voting. ${ }^{37}$

At the 332nd meeting of the Third Committee, delegates voted on a revised joint compromise text on the refugee definition to be applied within the statute of the High Commissioner's Office and in the draft Convention. Following a suggestion of the U.K. delegate, two draft definitions were agreed upon. Although still too restrictive for many delegations, including the U.K. and the states of the Indian subcontinent, these definitions were considered a triumph of the "universal definition." Yet, as Hathaway notes, "the eurocentric goal ... was achieved by limiting the scope of mandatory international protection under the Convention to refugees whose flight was prompted by a pre-1951 event within Europe." 38

Another suggestion of the United Kingdom delegation was that a Conference of Plenipotentiaries from interested states should be convened in Geneva in 1951 in order to devise a final draft of the Convention. It was accordingly decided that a special conference should be held, which would operate outside the parameters of the United Nations; this would enable non-members of that organization, which had a special interest in the issue of refugees, to participate. Consequently, states such as West Germany, Italy, and Austria, which had substantial refugee populations on their territory, and Switzerland and the Vatican, who had historically been concerned with the problem of refugee flight, were invited to the conference. On June 11, 1951, Pakistan provided a brief comment to the conference on article 26 of the draft Convention, which dealt with the freedom of movement of refugees. Nevertheless, neither India nor Pakistan played any substantial part, nor was either officially represented, in the conference. During a subsequent vote of appreciation, proposed by the United States in August 1951, for the work of the IRo, both India and Pakistan mentioned again their particular experience of refugee movement. However, it is impossible to know if this was a deliberate attempt to remind the international community of the traumatic events with which they had recently dealt, on their own. ${ }^{39}$ 


\section{Conclusions}

As noted above, nearly fifty years later, neither India nor Pakistan, nor indeed any other state in the Indian subcontinent, has signed the 1951 Refugee Convention. This refusal to accede to the Convention originated in the opinion that the United Nations High Commissioner for Refugees was an instrument of the cold war, and consequently not relevant to the situation of the Indian subcontinent within the international system. Such an opinion is not entirely misplaced. Gordenker claims that "the United Nations Convention for Refugees emerged from the American-led policy process of the United Nations." ${ }^{\circ 0}$ The growing ideological divide between the East and the West convinced the United States that the reconstruction of Europe was its most pressing priority. Consequently, despite the fact that it had earlier been the main financial contributor to the IRO and UNRRA, it was not willing to commit funds to an organization that dealt with the refugee problems of states largely marginal to its strategic aims. Inevitably, therefore, the United States "more or less ignored" the massive movement of Partition refugees because of the negligible political impact of the subcontinent on a bipolar world. However, on the other hand, it was politically expedient to maximize the international visibility of the migration of political refugees from the Soviet bloc. Hence the American support for a "temporary refugee agency with a narrow authority and limited function ... and a restricted definition of refugees within the Convention." ${ }^{41}$ The clear pro-Western orientation of the emerging refugee regime ensured that Yugoslavia, a state beginning to chart its own independent course in world politics, was the only Communist country represented in the Conference of Plenipotentiaries.

India and Pakistan came away from the negotiations surrounding the birth of the post-war international refugee regime with mixed feelings. Although they agreed with the need to set up a legal framework of refugee protection, they were acutely disappointed that this regime was not prepared to recognize the tremendous refugee burden under which they laboured, and to recognize that nonEuropean refugee movements must also be of concern to the international community. In the early 1950 India publicly took the view that, since it had no direct concern with the refugee issue as it was defined within the United Nations Convention, India did not wish to compromise its neutral status by getting involved. In 1953, the permanent representative of India to the un discussed India's attitude towards the international refugee regime with the High Commissioner for Refugees, and promised to direct the
Ministry of External Affairs to re-examine the issue. Mr. Aamir Ali, UNHCR representative for the Far East, visited India later that year to discuss the question of the UNHCR with the government of India. In a meeting with the foreign secretary, Mr. R. K. Nehru, he was told that "you [the UNHCR] help refugees from the so-called non-free world into the free world. We do not recognise such a division of the world." ${ }^{2}$ Similarly, in meetings with the Pakistani deputy secretary for un Affairs in the Ministry of Foreign Affairs, in April 1953, Ali was informed of Pakistan's desire to propose an amendment to the UNHCR statute. However, as Ali noted, the deputy secretary "was very resentful of UNHCR. He said that the Pakistani delegation had been encouraged by various UNHCR officials to broach the question of an amendment, but when the delegation had discussed such a move with other delegations it had run into a brick wall of opposition." 43 The disillusionment of the two South Asian states with the realpolitik of an ostensibly non-political refugee regime is evident.

Even in the aftermath of the 1967 Protocol, which removed the temporal and spatial limitations of the 1951 Convention, both states have preferred to conduct ad hoc agreements with the UNHCR rather than accede to the Convention. UNHCR has periodically urged the states of South Asia to reconsider their decision on accession. However, these states continue to view the Convention and Protocol as irrelevant to the refugee experience of South Asia. Officially, South Asian governments maintain that their reluctance to accede to the Convention stems from the fact that it does not cater to situations of mass influx or to mixed flows of migrants, both of which characterize forced population flows in this region. In addition, they claim that the Convention represents an imbalance between the rights and obligations of source and receiving countries, and that the principle of international burden sharing is inadequately institutionalized within the regime. It is important, however, that some commentators further locate this hesitation in the desire of the states of the Indian subcontinent to retain a significant degree of autonomy in their refugee policies. Few institutional mechanisms have been created for the protection of refugees by governments in this region in the last fifty years - a fact that has led to criticism of South Asian refugee policy as ad hoc, arbitrary, and even biased towards particular refugee groups. Yet, the states of South Asia maintain, with some measure of credibility, that they have respected the "spirit if not the letter" of the 1951 Convention and 1967 Protocol. Noting recent attempts by some Western governments to modify, or even negate, both the spirit and the letter of these instruments, ${ }^{44}$ states such 
as India and Pakistan have lately re-emphasised their opposition to accession. ${ }^{45}$ This policy stance can be seen, in many ways, as a legacy of the frustrating deliberations that took place in the United Nations between 1947 and 1951.

\section{Notes}

1. Defined for the purposes of this article as India, Pakistan, and Sri Lanka. Bangladesh, formerly East Pakistan, gained its independence from West Pakistan in 1971.

2. Ceylon (renamed Sri Lanka in 1972) gained its independence from Britain on February 4, 1948, but became a member of the United Nations only on December 14, 1955. Consequently, it did not take part in the debate on the creation of the UNHCR, or the 1951 Refugee Convention. Ceylon's membership application was blocked by a Soviet Union veto on three occasions, on the grounds that Ceylon was not a fully sovereign state. Under agreements conducted with the United Kingdom at independence, Ceylon allowed the presence of British air and naval bases and armed forces on the island. However, a more compelling reason for the Soviet veto was the British and American veto on the entry of a number of Communist-bloc states at around the same time.

3. Sir Bengal Narsinga Rau, India's representative on the third session of a joint meeting of the Second and Third Committees remarked that "his country's draft constitution, which would soon be considered by the Constituent Assembly, embodied most of the rights set forth in the draft declaration [of human rights]." un, Third Session, First Part, Joint Second and Third Committees, Ninety-first Meeting, October 2, 1948, Official Records.

4. un, Third Session, First Part, Plenary Meeting, September 25, 1948, paragraph 143. India's view of the un can be gauged from the following speech made by Mrs. Pandit who, in 1947, declared, somewhat optimistically, "Our organisation, the United Nations, has no 'isms' of its own; it embraces all 'isms' and ideologies, it embraces all civilisations of the West and of the East, its principles cannot be said to derive exclusively from either or any of the contending doctrines." Quoted in M. C. Setalvad, "India and the United Nations," India Quarterly 6, no. 1 (January-March 1949): 112.

5. Speech in the United States, February 1948, quoted in K. Sarwar Hasan, Pakistan and the United Nations (New York: Manhat$\tan , 1960), 301$.

6. Talat A. Wizarat, "Pakistan and the United Nations," Pakistan Horizon Quarterly 40, no. 1 (1987).

7. S. M. Burke and L. Ziring, Pakistan's Foreign Policy: An Historical Analysis, 2nd edition (Karachi: Oxford University Press, 1990), 136.

8. un, Fifth Session, Ad Hoc Political Committee, December 4, 1950, Official Records, paragraph 26.

9. William Henderson, “The Refugees in India and Pakistan," Journal of International Affairs 7, no. 1 (1953): 57-65.

10. Government of India, External Affairs Department, Report by V. K. Krishna Menon on Visits to Various European Capitals (New Delhi: Government of India Press, 1946), 41. In addition is the following exchange that took place in the Legislative Assembly, March 11, 1947, on Government of Inda association with the UN Rehabilitation and Reconstruction Association:

Mr. Manu Subedar: "Will the Hon. Member tell this House that if three crores contribution was made by India, in a year of distress, for the relief of others, whether this country received anything from any part of the world?"

Hon. I. I. Chundrigar (Commerce Member): "There has been little assistance from other countries..."

Subedar: "In view of this experience of India that in our distress nobody comes to our aid, Gor should lessen international aid?"

Government of India, Legislative Assembly Debates 3, no. 1, New Delhi, March 1947.

11. The issue of the Partition refugees was not, however, the Indian subcontinent's first experience with issues of forced migration, or indeed of hosting refugees albeit on a greatly different scale, in the contemporary period. In a census conducted by the Commonwealth Relations Department in November/December 1943, it was revealed that nearly 400,000 evacuees who were Asiatic British subjects, and 11,368 European and foreign evacuees had arrived in India in search of refuge from the hostilities of the Second World War after September 8, 1941. Also, both states indicated in October 1949 to the International Refugee Organisation (IRO) that "they considered themselves bound by the signature of the former Government of India" on the London Travel Agreement of October 15, 1946, and would therefore continue to issue IRo travel documents to persons recognized within the IRO mandate. See Reply to Starred Question No. 202, 1945. mEA File No. 1/5/45 - Public (e), National Archives of India.

12. J. G. Stoessinger, The Refugee and the World Community (Minneapolis: University of Minnesota Press, 1956), 99.

13. For an account of the working and history of the Iro see M. J. Proudfoot, European Refugees: A Study in Forced Population Movement 1939-1952 (London: Faber and Faber, 1957).

14. The draft resolution also sought to recognize "the principle that where population movements are likely to impair friendly relations between nations, such movements should take place only with the consent of the States directly concerned." This somewhat unrealistic proposition should be seen in the context of the population flows between Pakistan and India that had just started to reach crippling proportions. Also, the very fact that India sought at this time to stress the principle of voluntary repatriation of refugees to their country of origin indicates that the Partition refugee flows were not merely seen as straightforward population exchanges, as has been suggested by some commentators. un, Second Session, Third Committee, Seventyninth Meeting, Annex 12d, November 6, 1947, Official Records.

15. UN, Ninth Session, Ecosoc, 326th Meeting, August 6, 1949, Official Records, 628.

16. In the initial stages of the discussion, however, the United States asked merely that the question be referred to an ad hoc committee for consideration. Consequently, Eleanor Roosevelt asserted on November 8, 1949, that "in the circumstances, it would seem that the ad hoc committee [established by Ecosoc] would be qualified to recommend to the General Assembly those cat- 
egories of refugees which, in addition to those provided for in the Iro Constitution, should become the concern of the High Commissioner for Refugees." un, Fourth Session, Third Committee, 257th Meeting, November 8, 1949, Official Records, paragraph 76 .

17. un, Fourth Session, Third Committee, 261st Meeting, November 12, 1949, Official Records, paragraph 38.

18. UN, Fourth Session, Third Committee, 26oth Meeting, November 11, 1949, Official Records, paragraph 5. This view stemmed essentially from the idea, expressed by Eleanor Roosevelt, that there was a need "to preserve the essentially deliberative character of the United Nations, because there was an increasing tendency to drive the United Nations into the field of international relief." un, Fourth Session, Third Committee, 262nd Meeting, November 14, 1949, Official Records, paragraph 7. In light of the current direction in which UNHCR activity is increasingly headed, this opinion seems especially ironic.

19. Mr. Fearnley, the U.K. delegate, accordingly stated that "any other than a broad definition would seriously impede the High Commissioner's freedom to advise on general refugee problems.” Ibid., paragraph 39.

20. UN, Fourth Session, Third Committee, 256th Meeting, November 9, 1949, Official Records, paragraph 18.

21. UN, Fourth Session, Third Committee, 258th Meeting, November 11, 1949, Official Records, paragraph 22.

22. Eleanor Roosevelt noted that "these problems should not be concerned with the problem before the General Assembly, namely the provision of protection for those outside their own countries, who lacked the protection of a Government and who required asylum and status in order that they might rebuild lives of self-dependence and dignity." un, Fourth Session, Joint Third and Fifth Committees, 264th Plenary Meeting, December 2, 1949, Official Records, paragraph 73. The fact that there was little international aid forthcoming for the Partition refugees, who also needed to rebuild their lives, was largely ignored in these discussions.

23. The representative from Lebanon accordingly asserted that "it seemed to him that the United Nations should be equally, if not more, concerned with the problem of the Arab refugees from Palestine, whose situation was a direct result of one of its own decisions." un, Third Session, Second Part, Third Committee, 228th Meeting, May 12, 1949, Official Records, paragraph 457.

24. As would be expected, states argued according to their perceived "national interest." Consequently, the creation of a regime with the ability to disburse material aid to refugees was opposed by the U.S. and U.K. for widely divergent reasons. While the U.K. was not, for geographical reasons, likely to need funds for the mass resettlement of refugees on its territory, the U.S. Congress had, by 1950 , begun to veto the grant of funds to international organizations that included states of the Soviet bloc. On the other hand, France was broadly in favour of funds for refugee aid because of its land borders with Germany and consequent fears that it might one day have to host large numbers of refugees from that country. For more on this point, see Kim Salomon, Refugees in the Cold War: Towards a New International
Refugee Regime in the Early Post-war Era (Lund, Sweden: Lund University Press, 1991), 228-30.

25. UN, Fourth Session, Third Committee, 263d Meeting, November 15, 1949, Official Records, paragraph 60.

26. UN, Fourth Session, Third Committee, 26oth Meeting, November 11, 1949, Official Records, paragraph 37.

27. Salomon, Refugees in the Cold War, 231.

28. Also, it is difficult to envisage a truly global refugee regime that was prepared to ignore, to all intents and purposes, the greatest forced movement of persons in contemporary history. There is a sense in these deliberations that what was being created, despite the rhetoric of universality, was a tailor-made solution to a specific problem. It is this sense of exclusion, on the grounds of political expediency, that India and Pakistan took with them when they left the United Nations deliberations.

29. See James C. Hathaway, The Law of Refugee Status (Toronto: Butterworth, 1991), and G. Loescher and L. Monahan, Refugees in International Relations (New York: Oxford University Press, 1989).

30. In November 1949 India accordingly argued that "poor countries, such as India, realised that [the estimate of $\$ 750$,00o for the functioning of the High Commissioner's Office] was a considerable sum. It would be difficult for India to contribute to a budget to be used only for the legal protection of certain refugees when there were millions of refugees in dire need on its own territory." uN, Fourth Session, Third Committee, 26th Meeting, November 15, 1949, Official Records, paragraph 59. Pakistan further asserted that "if the proposal before the Committee was adopted, Pakistan would have to share in financing the legal protection of an undefined number of refugees in Europe, while obtaining no benefits for the millions of refugees in its own country." un, Fourth Session, Third Committee, 26oth Meeting, November 11, 1949, Official Records, paragraph 37.

31. India's representative stated "in spite of its own difficulties, it would have voted for the establishment of a High Commissioner's Office if it had been convinced that the need for it was imperative. It did not think, however-and the discussion had confirmed that opinion - that there was any great need to set up an elaborate international organisation whose sole responsibility would be to give refugees legal protection. At a time when its own refugees were dying of starvation, it would be obliged to vote against all the Resolutions submitted." un, Fourth Session, Third Committee, 263rd Meeting, November 15, 1949, Official Records, paragraph 62.

In his statement, the Pakistani representative declared that "when he asked that the IRo should continue looking after its own refugees and not burden the whole of the United Nations with that task, he was doing no more than the member states of IRO themselves when they told Pakistan to look after its own refugees without any help from the United Nations in the guise of a High Commissioner. In view of the above considerations, his delegation would vote against the joint draft Resolution before the Committee." un, Fourth Session, Third Committee, 264th Meeting, November 15, 1949, Official Records, paragraph 12.

32. The statute of UNHCR was eventually approved by the General 
Assembly in Resolution 428 (v) of December 14, 1950.

33. UN, Eleventh Session, ECOsoc, 399th Meeting, Minutes, August 2, 1950, Official Records.

34. Un, Fifth Session, Third Committee, 325th Meeting, November 24, 1950, Official Records, paragraph 36.

35. See Louise Holborn, Refugees: A Problem of Our Time (Metuchen, NJ: Scarecrow Press, 1975), 81.

36. un, Eleventh Session, Ecosoc, 399th Meeting, Minutes, August 2, 1950, Official Records.

37. un, Fifth Session, Third Committee, 332nd Meeting, December 1, 1950, Official Records, paragraphs 26-7. The Pakistani delegate had earlier declared in the Third Committee that "he had gathered the unfortunate impression that some delegations entertained serious doubts as to the purely humanitarian aspect of the problem, and also that politics had perhaps made an unwelcome intrusion into the question ... He deplored a situation in which refugees might find themselves mere pawns on the international chess board." un, Fourth Session, Third Committee, 264th Meeting, November 15, 1949, Official Records, paragraph 5.

38. Hathaway, The Law of Refugee Status, 84.

39. So, while the Indian delegate "said that his country fully appreciated the difficulties involved in the resettlement of refugees, and considered that the Iro had done an excellent job," the delegate from Pakistan "expressed his delegation's wholehearted support for the us draft Resolution, since the experience of his own country in dealing with six million displaced persons from India at the time when Pakistan had been establishing itself as an independent state, had made him fully aware of the tremendous work which the IRo had accomplished." un, Thirteenth Session, Ecosoc, 526th Meeting, August 29, 1951, Official Records, paragraphs 71-87.

40. Leon Gordenker, Refugees in International Politics (New York: Columbia University Press, 1987), 87.

41. Salomon, Refugees in the Cold War, 232.

42. Archives of the United Nations High Commissioner for Refugees, Progress Report No. 3, 15 December 1953, 6/1/INDIA Protection-General-India, Series 1, Fonds 11.

43. Archives of the United Nations High Commissioner for Refugees, Report of Aamir Ali's Mission to Pakistan, March/April 1953, 6/1/PAK Protection-General-Pakistan, Series 1, Fonds 11.

44. On the changing nature of the asylum regime, see Adam Roberts, "More Refugees, Less Asylum: A Regime in Transformation," Journal of Refugee Studies 11, no. 4 (1998): 375-95.

45. Accordingly, the Joint Secretary (un Division) in the Indian Ministry of External Affairs noted recently that "even Western states are now whittling down the conception of asylum, which points to flaws in the 1951 Convention and makes us very reluctant to accede to it." Interview conducted by the author, New Delhi, May 1, 2000.

Pia Oberoi is a final year doctoral candidate in the Department of International Relations at St. Antony's College, Oxford University. Her thesis focuses on the refugee policies of South Asian states from 1947 until the present.

(C) Pia Oberoi, 2001. This open-access work is licensed under a Creative Commons Attribution-NonCommercial 4.0 International License, which permits use, reproduction and distribution in any medium for non-commercial purposes, provided the original author(s) are credited and the original publication in Refuge: Canada's Journal on Refugees is cited. 